\title{
Disaster, Debt, and 'Underdevelopment': The Cunning of Colonial-Capitalism in the Caribbean
}

\author{
Levi Gahman ${ }^{1,2} \cdot$ Gabrielle Thongs $^{1} \cdot$ Adaeze Greenidge $^{1}$
}

Published online: 17 March 2021

(c) Society for International Development 2021

\begin{abstract}
This article provides a critical overview of the structural forces exacerbating risk related to disasters in the Caribbean. It focuses on the historical antecedents and socio-environmental consequences of extreme weather events across the region via an anti-colonial analysis of Hurricanes Irma and Maria in 2017 and Dorian in 2019. The authors contend that the logics, practices and debts of colonial-capitalist development, neoliberal exploitation and post-independence corruption continue to reduce resilience and threaten public health in the region. They also detail the role that political economy and social geography play in the face of disasters. They end by proposing that future critiques of and solutions to vulnerability, disaster, and catastrophe in the Caribbean be more attentive to the historical trajectories of imperialism, debt and 'underdevelopment'.
\end{abstract}

Keyword Caribbean · Disasters $\cdot$ Imperialism $\cdot$ Underdevelopment $\cdot$ Climate change $\cdot$ Debt $\cdot$ Frantz Fanon

\section{The Current (Caribbean) Reality}

As evidenced by countless international reports about Hurricanes Irma and Maria over the past three years—not to mention Hurricane Dorian and the COVID-19 pandemic more recently-escape has not been an option for most in the Caribbean. Gales swept through the islands, homes were torn asunder, costs accrued, contaminants accumulated, disease spread and lives have been lost (Sheller 2018). ${ }^{1}$ Indeed, what were once predictable changes to the wet and dry months in the region are now increasingly erratic patterns of atmospheric tumult. Intensifying disaster events and reductions in resilience are the outcome (IPCC 2014), which demand more funding, resources and labour to allay escalations in damage and harm (Grove 2014). There is widespread agreement, based on meteorological data and lived experience, that Caribbean seasons, noteworthy for shifts in temperature and precipitation, are changing (Pulwarty et al. 2010). That

All contributors agree that lead authorship is shared and interchangeable.

Levi Gahman

Levi.Gahman@liverpool.ac.uk

1 University of the West Indies, St. Augustine, Trinidad and Tobago

2 University of Liverpool, Liverpool, UK this is all coinciding with the COVID19 pandemic only adds to the distress.

As people living and working in the Caribbean who continue to navigate the ramifications of recurring extreme weather events, sometimes we wonder if 'change' is an appropriate enough term to describe the region's climate regime. Reports of rising sea levels, torrential rains and persistent flooding (Karmalkar et al. 2013), coupled with coastal erosion, habitat devastation, agricultural destruction, higher food import bills, emotional grief and time lost picking up the pieces are all growing in number throughout the region (Adger et al. 2005; Taylor et al. 2012). Across the islands, the forfeiture of homes and human life that resulted from Irma, Maria and Dorian remain and reverberate. Countless families, too, wait with bated breath to see what aftermath COVID-19 will bring.

\footnotetext{
${ }^{1}$ In discussing these disaster events and deaths in the Caribbean, we do so with recognition of the dignity, and in solemn remembrance, of those who perished because of the catastrophes in mention. We also do not write without offering an acknowledgement of the anguish experienced by the friends/family members of those who lost loved ones and/or suffered needlessly. Finally, it is critical to avoid defining a place or group by they are perceived to be lacking or solely by the pain they experience. As such, we note that the empathy, joys, dreams, mutual aid and hopes of Caribbean persist - just as much as, if not more, than the pain.
} 


\section{'Development' in the Caribbean}

Whilst the vast majority of the nation states in the Caribbean have been purportedly independent since the 1960s-1970s, they are marked by a particularly interesting, that is, paradoxical, type of political sovereignty and experience of development (Greenidge and Gahman 2020). Noted Caribbean Marxist scholar Norman Girvan (2015) argued for decades that 'decolonization' in the region remains incomplete. Indeed, it has come to a virtual standstill. For gender and development expert Eudine Barriteau (2001), development has been put at the service of foreign private capital and former colonial powers-rather than local people, communities and civil societies. Barriteau goes on to note that the Caribbean desperately needs to rediscover a strategic orientation driven by repurposed, invigorated and non-corrupt institutions. Some regional development analysts posit that although the 1970s began with a political revolution in many of the islands, it ended with an industrial one, which opened the door to capitalist logics, colonial mimicry, and the predation of the IMF (Beckford 1972; Young 1976; Levitt 2005). Consequently, the region continues to be plagued by plantation logics (Best 1968), the Westminster system (Girvan 2015), debt and import dependency (Barry et al. 2020) and heteropatriarchal social relations (Barriteau 2001). And as postcolonial political geography scholars (Rhiney 2018; Mollett 2016; Noxolo 2018) assert, much of the Caribbean is currently coping with its most prolonged and complex development crisis vis-à-vis in/security, vulnerability and resilience since emancipation.

Caribbean feminist Michelle Rowley expands upon critiques of development in the region by critically analyzing it as a discourse, as well as what it both signifies and produces for the Caribbean. She argues that the 'civilising mission of development has historically been an inherent exercise of power among disparate and hierarchically ordered subjects and locations' (Rowley 2003: 75). Noting that (capitalist) development logics have been promoted and lauded through a range of differing political ministries, social institutions and genres of media, marketing, and advertising, she suggests that, at its core, development is an ideology born and refined in the Global North-a Western ideology devised largely to meet the needs of (neo) colonial agents that were in search of a more 'appropriate' and palatable tool than naked violence for their economic and geopolitical expansion (Rahnema and Bawtree 1997).

In short, conventional notions of development were a manufactured phenomenon that operated for the benefit of those who created it; namely, Western powers and imperialists. Guyanese historian Walter Rodney (1972) avows that development became a doctrine that aided and abetted a dying and obsolete colonialism, allowing it to transform into an aggressive (sometimes even attractive and seductive) instrument to (re)capture land, labour and capital, as well as to create new markets. Indeed, no mention of imperialism as the highest phase of capitalism need be made when a state, corporation or bank can call it 'development'. This typifies the Caribbean experience. The underlying-yet all too loud and clear-message of the vast majority of 'development projects', which have allegedly been carried out on behalf of grassroots people across the region, has been that homegrown modes of living, thinking, doing and being in the Caribbean are primitive, static and condemning them to lives of stagnation and torpor.

Rodney (1972), in his incisive diagnosis of global capitalism, maintains that the asymmetrical extractive nature of Western development (i.e., 'underdevelopment') poses an ongoing threat to former colonies when he states:

Obviously, underdevelopment is not absence of development, because every people have developed in one way or another and to a greater or lesser extent. Underdevelopment makes sense only as a means of comparing levels of development. It is very much tied to the fact that human social development has been uneven and from a strictly economic viewpoint some human groups have advanced further by producing more and becoming wealthier.

Economically, as he points out, development revolves around exploitative ideas and extractive practices of putatively 'free trade', privatization, industrial production and the transfer of wealth/resources. Critical insights like this offer clarity on how 'development' is largely a process of siphoning and accumulating capital. Development, in turn, is wielded as a monolithic hierarchy-inducing discourse that defines 'Others' by what they are ostensibly thought to be lacking, as well as where they are conceived to be on a fictive linear timeline.

Before getting into the substance of our analysis of debt and disaster in the Caribbean, we offer a caveat about two of the terms we use throughout: 'colonial-capitalism' and 'underdevelopment.' In finding elucidatory vision in the radical analysis of political revolutionary Frantz Fanon (1963), we deliberately use 'colonial-capitalism' to signify the mutually constitutive and inextricable links that exist amongst capitalist logics and colonial power. These indissoluble relationships, i.e., those between the practices/processes of colonialism and capitalism, continue to be highly influential in how governance, societies, economies, and certain cultural norms have been fashioned and operate within the Caribbean (Levitt 2005). We therefore feel it crucial to explicitly signal and fasten colonialism to capitalism, noting well that each are undergirded by 
racialism (Fanon 1963) and patriarchy (Mohanty 1988; Jones 2017). We do this primarily because the form and function of capitalism, especially in the Caribbean, was and remains inseparable from colonial worldviews, institutions and social relations.

Specifically, we draw our reasoning for the use of "colonial-capitalism' from Fanon's Les Damnés de la Terre (1963), which cogently describes the indivisible ties that bind together not only race, colonialism and capitalism, but also sovereign debt and post-independence complicity with exploitation and injustice. A few instructive lines highlighting these dynamics can be seen throughout the book. Chiefly, when Fanon writes:

After a phase of capital accumulation, capitalism has now modified its notion of profitability. The colonies have become a market. The colonial population is consumer (1963: 26)

Capitalism therefore objectively colludes with the forces of violence that erupt in colonial territories (1963: 27)

Colonialism and imperialism have not settled their debt to us once they have withdrawn their flag and their police force from our territories. For centuries, the capitalists have behaved like war criminals in the underdeveloped world (1963: 57)

In colonized territories, after independence, the [national] bourgeois caste draws its main strength from [economic] agreements signed with the former colonial power (1963: 120).

Much like Fanon (1963) and Rodney (1972), we also use the term 'underdeveloped'. Markedly, its meaning denotes neither a fixed intrinsic status nor an ordinal international rank. Rather, we deploy it politically, in a manner suggesting that certain spaces, places, populations and communities-which have been negatively racialized and deemed profane (e.g., Third World, Global South, peripheral North [reservations, 'ghettos,' barrios, trailer parks], Majority World)—were and continue to be actively targeted for extraction, repression and domination.

Put differently, our use of 'underdeveloped' implies neither an objective state of being nor a subordinate status. It simply means that, in most cases, if we hear or read of a place that is 'underdeveloped' (or 'developing' or 'lesser development' for that matter) we, similar to Rodney and Fanon, now intuitively think of a group and/or geography that has been intentionally placed in the crosshairs and deliberately ambushed by hostile forces. Our key assertion, thus, is that vis-à-vis the nexus of risk and climate change in the Caribbean, colonial-capitalism and the reasons why a particular country/region is 'underdeveloped' continue to matter apropos both reduced disaster resilience and threats to public health.

\section{Hurricanes Irma, Maria, Dorian...}

Undeniably, the rapid formation and respective fallouts of Irma and Maria in September 2017 and Dorian in 2019 caught the world's attention. They put the Caribbean on the front page. Prior to these, however, in early 2017, tropical storms Bret and Don reached as far south as Trinidad, an island that had previously seen a total of only four hurricanes since record-keeping began in 1851 (Caribbean Storm Network 2011). In fact, over the course of only a month, the convergence of clouds formed by the churning of warm waters in the Atlantic Basin spawned four fully formed hurricanes (Irma, Jose, Katia and Maria) just weeks after tropical storm Harvey passed through the eastern Caribbean in mid-August 2017. The region had not seen activity of this nature since 2010, when Hurricanes Igor and Karl joined Julia to bring disaster. The storm generation represented by the increased magnitude and heightened forms of Irma, Maria and now Dorian are quickly becoming an expectation in the region-what some refer to as a 'new normal.'

As a reminder, in 2017, Hurricanes Irma and Maria's respective paths of destruction distressed more than 15 Caribbean countries and archipelagos. This represents a significantly higher number of islands than those affected in 2010 by Hurricanes Igor, Julia and Karl combined, which only directly impacted Bermuda and Cape Verde. In stark contrast, Irma and Maria made landfall in Dominica, Antigua, Barbuda, Anguilla, the British Virgin Islands, the U.S. Virgin Islands, Turks and Caicos, the Dominican Republic, Puerto Rico, St Kitts, Nevis, Cuba, St. Maarten, St. Martin, St. Barthélemy Tortola and Guadeloupe, among others. Not coincidentally, Bermuda and Cape Verde have substantially higher GDP- and GNI-per capita than Barbuda and Anguilla, which strongly correlates to greater resilience, quicker recoveries, and more expedient social and environmental recuperative efforts (Kahn 2005).

Dominica, the island on the frontlines of Maria's category $5170 \mathrm{mph}$ winds, is where the hurricane first made landfall. The resulting devastation led to nearly US $\$ 1.5$ billion in losses, more than double the country's GDP, with over $95 \%$ of the nation's buildings being damaged (Suliman 2018). Afterwards, in a rousing statement to the United Nations, Prime Minister Skerrit of Dominica (2017) noted the island looked like 'a war zone' while offering an unyielding challenge to the 'developed' world: '...to deny climate change is to procrastinate while the earth sinks.... While the big countries talk, the small 
island nations suffer. We need action and we need it now.' Relatedly, in Barbuda, Irma destroyed more than $90 \%$ of the housing stock and telecommunications infrastructure. Meaning, large groups of people became reliant upon flyover rooftop rescues by emergency responders (Phipps 2017). Similar incidents were reported from other islands as a result of Maria. By comparison, although serious damage was reported in Bermuda and Cape Verde, nothing as devastating occurred. Those two islands were able to return to typical day-to-day activities more quickly than islands with fewer economic resources, particularly those where roads and electricity were cut off.

Puerto Rico's recovery, too, was hampered by flooding in residential, agricultural and commercial areas. Turbulent winds destabilized transport and communication infrastructure, consequently meaning thousands of people were left isolated and forced to chronically wait for information, medicine and support. Paramount here is that Puerto Rico's ability to cope was and continues to be severely manacled by its de facto status as a dependency of the United States (Briggs 2003; Arnold 2019). Effectively a US colony since 1898 , Puerto Rico has not avoided the compromising penchants of imperial encroachment since it was invaded (Briggs 2003). Whilst occupied by the burgeoning power, the USA enacted a slate of edicts as a means of establishing rule of law over, and indebting, Puerto Rico's populace. In turn, any prospect of territorial sovereignty and aspiring towards political independence was arrested.

This colonial present, along with the Trump Administration's benighted handling of recovery efforts after Irma, which resulted in prolonged logistical delays and widespread criticism, reached a flashpoint within a matter of days. Subsequently, thousands of scholars, activists and journalists cumulatively spoke out against how entrenched imperial mentalities and policies underpinned the US government's numerous botched attempts with assisting those in urgent need. In an elucidatory critique of the situation, an open statement signed by hundreds of academics cast necessary critical light on the humanitarian crisis (Sotomayor et al. 2017). The illuminating testimonial historicizing Puerto Rico's geopolitical reality reads, in part, as follows:

Puerto Rico is a colony of the United States. Its political status stems from the U.S. invasion of 1898 and a series of laws that served only to consolidate U.S. control, hindering the possibility of Puerto Rican sovereignty and political emancipation...

...U.S. citizenship of Puerto Ricans, in this circumstance, is not a privilege, but the branding of a slave... Puerto Rico cannot be rebuilt on the basis of an unpayable and fraudulent debt. Both laws [the Jones Act and PROMESA] condemn the country to an unsustaina- ble economic future that will intensify the exodus of Puerto Ricans from their island. ${ }^{2}$

This overview of how imperial aggression, colonial-capitalism and consolidated state power/law has quarantined and rendered people vulnerable - as well as placed the island in debt bondage - clearly demonstrates how Puerto Ricans continue to remain, as Sotomayor et al. (2017) avow, 'hostages of their colonial condition.'

\section{Damage, Debt, and Public Health}

Damage caused by disasters in the Caribbean is frequently amplified by situational susceptibility, needlessly protracted and incomplete recoveries and massive debt burdens/servicing (Trotz and Lindo 2013; Hares 2016). In 2004, for example, Hurricane Ivan rolled roughshod through the basin with unremitting category 5 windspeeds of $160 \mathrm{mph}$. The region's economy took more than three years to recover. Grenada's surplus of US\$17 million became a deficit of US\$54 million thanks to decreased revenue and the outlays for rehabilitation and reconstruction. Hurricanes Irma, Maria and Dorian are thereby just the latest examples of intensified extreme disasters to wreak havoc in the Caribbean, with their fallout still commanding attention at this time. This is largely because either Maria or Irma would have been one of the region's most destructive climate events on record, with Dorian registering just behind.

That this damage was absorbed by the region within a span of two years makes the catastrophe it faces all the more surreal. Damage and catastrophe incurred are due in part to low levels of economic development (i.e., underdevelopment) - an outcome many argue is directly linked to colonial dispossession, enslavement, indentureship, debt bondage and dependency dating back centuries (Sealey-Huggins 2017; Sheller 2018). Worth mention here is that none of hurricanes preceding Irma and Maria were as devastating as either one of their respective category 5 assaults, which to date has caused approximately 3,000 confirmed deaths, displaced thousands and left countless dealing with aggravated posttraumatic stress disorder (PTSD) (Milken Institute of Public Health 2018; Scaramutti et al. 2019). Similarly, Dorian, too, caused dozens if not perhaps hundreds of deaths, cost over US\$7 billion and left thousands homeless in the Bahamas (ReliefWeb 2019).

\footnotetext{
2 To read the statement in its entirety:

https://www.commondreams.org/views/2017/09/30/cruelest-storm200-academics-speak-out-puerto-rico?utm_campaign=shareaholic $\&$ utm_medium=twitter\&utm_source=socialnetwork.
} 
Across the Caribbean, those whose lives have been thrust into upheaval and remain without shelter as a result of disasters like this are street dwellers, homeless people, squatters, and others living in precarious rural, hillside and coastal areas-settings that are prone to landslides, collapse, and flooding (Wisner et al. 2014). Also rendered vulnerable, disproportionately, by such disasters are older people, children, disabled people, women and those with illnesses whose underlying conditions are aggravated by mold, poor nutrition, lack of potable water, unavailable medicine and inaccessibility to health professionals (Hemingway and Priestley 2014). These realities are exceptionally disconcerting in the face of the COVID-19 pandemic. Most, if not all, disaster emergency shelters across the region were not designed to attenuate the spread of communicable diseases. Throughout the region, there is also no shortage of high-density settlements (informal and formal) and multigenerational households that see a number of living persons in small fixed spaces or 'yards'. In turn, if a high-intensity disaster occurs where residents are required to evacuate to emergency shelters there is high likelihood that an infectious disease could spread both rapidly and en masse.

Furthermore, with most of the public and private workforces in the Caribbean either on lockdown or sheltering in place due to the coronavirus outbreak, both government revenues and personal incomes will decrease whilst social safety net expenditures increase. This is especially true for both tourism and agriculture industries, upon which a number of Caribbean small island states and economies are highly dependent. Finally, as the virus spreads regionally, a substantial amount of capital is necessarily being used to support healthcare efforts. This means fewer funds will be available for disaster preparation, mitigation and eventual recovery efforts should any disasters strike during the pandemic. That numerous Caribbean countries are facing unsustainable and 'dangerous' debt-to-GDP ratios and servicing sovereign debt - rather than public health and disaster prevention-is an injustice in urgent need of reparation.

More succinctly, since 2017, the Caribbean has been relentlessly battered by three separate major hurricanes, any of which in disaggregate would be classified amongst the region's most severe and costly. Numerous countries, and more appositely, local communities and ecological niches have been made precarious in a twofold manner. First, geophysically, as small island nation states and territories with people, animals and plants living with the actualities of rising sea levels and extreme weather events. And second, geopolitically, due to the domination, exploitation, debt and corruption Caribbean societies have been subjected to and continue to face as a result of their unique yet shared colonial histories and postcolonial 'present-days'.

That is, over the past three years, Hurricanes Irma, Maria and Dorian have provided the rest of the world with a brief glimpse of the 500-years-in-the-making disaster that has always and wilfully been made visible for people in the Caribbean. In terms of solutions to these challenges - and from a governance perspective-both reparatory and development justice should be the starting point (Gahman and Thongs 2020). That is, debt cancellation, reparations and the transfer of wealth and resources back to targeted/underdeveloped countries, populations, and communities is necessary. Thereafter, a focus on sustainable, socially just, low-impact development projects-which jettison colonial-capitalist logics - is crucial. Projects characterized by actually existing transparency, democratic process, and participatory budgeting - that include civil society, regional specialists, local workers and social movements-then must carry the day to ensure that resources are equitably put at the service of the health, well-being, political education and overall resilience of differing Caribbean peoples, places and communities.

\section{Conclusion and Calling Back to Fanon}

Clearly, the impacts of events like Irma, Maria and Dorian and the course of the subsequent recovery are determined by a country's preparedness and capacity to respond (PenningRowsell et al. 2005). Hence, at national and regional levels, state attention and expenditures on disaster prevention, recovery services and public health and education can function as a protective shield. By contrast, a debt-induced lack (or mismanagement) of financial resources coupled with the confluence of failing to protect ecosystems, dismissals of climate science, ongoing corruption of regional governments and/or reductions of investment in social welfare pose grave threats to many living in small island developing states and 'underdeveloped' geographies.

Moreover, in the face of the unsustainable debt burdens that continue to plague the Caribbean, it is crucial to remain suspicious of the purported benefits that state-contingent debt instruments or other insurance-based mechanisms are advertised to offer. Countless debt solutions, even disasterrelated debt restructurings like temporary suspension or interest rate forgiveness schemes that are seemingly unavoidable to agree to, are driven by the same economic logics and geopolitical entities that generated many of the region's ruinous debt burdens in the first place. Indeed, sovereign debtservicing 'solutions' related to disaster events throughout the Caribbean have been used as a pretext to privatize social reproduction, grab land, cut corporate taxes, secure business contracts for foreign companies, and reorganize domestic relations within debtor countries to the advantage of multinational private capital or global economic superpowers like the United States. In addition, neoliberal approaches to disaster recovery efforts and public debt crises across the region have had the tendency to put ruling class elites, 
high-ranking members of political society, and members of the postcolonial national bourgeoisie of borrower countries in the service of external creditors and international financiers. In turn, the comparative authority, clout, and power of national technocrats and credentialed powerbrokers all increase whilst the actual burden of servicing sovereign debt amidst any given disaster is foisted onto the shoulders of the debtor country's local populace.

Despite this, from certain vantage points in the region and beyond, there remains the perception that disaster events, unsustainable debt, and dangerous climate change are all things that can be dealt with later-once neoliberal development, foreign direct investment and the societal internalization of an entrepreneurial spirit are shored up and scaled out. The cruel irony of this is illustrated by the fact that any serious review of the historical trajectory of the Caribbean will reveal that entrepreneurial colonial-capitalism has never served the region well-just as eliding committed action on climate change will not. Here, the West's refusal to pay reparations, culpability of multinational corporate extractors, inaction on the part of complicit Global North administrations, apathetic or distracted factions of regional governments and lack of accountability on the part of local state officials also need not go unchecked (Girvan 2015; Stapenhurst et al. 2018).

To conclude, while the Caribbean continues to recover from Hurricanes Irma, Maria and Dorian (whilst bracing for more) and coping with the COVID-19 pandemic, we call back to the Caribbean's own revolutionary thinker, Frantz Fanon. Fanon, who remains one of the world's foremost advocates of the reciprocal recognition of human dignity and taking colonizers to task, recognized the complexities of imperialism, capitalism and climate change posed more than half a century ago when he contended '...the soil needs researching, as well as the subsoil, the rivers, and why not the sun?' (Fanon 1963: 56). As the region looks for pathways out of the suffering wrought by the constellation of imperialism, ruinous debt, corruption, extreme disaster events and pandemic, Fanon's words seem like a good place to start. Because, indeed, who better to turn to during times of catastrophe-be it climate, colonial, capitalist or otherwise-than Fanon?

\section{References}

Adger, W. Neil, Terry P. Hughes, Carl Folke, Stephen R. Carpenter, and Johan Rockström. 2005. Social-ecological Resilience to Coastal Disasters. Science 309 (5737): 1036-1039.

Arnold, Carrie. 2019. Death, Statistics and a Disaster Zone: The Struggle to Count the Dead After Hurricane Maria. Nature 566 (7742): 22-25.
Barriteau, Eudine. 2001. The Political Economy of Gender in the Twentieth-Century Caribbean. Springer.

Barry, Tessa, Levi Gahman, Adaeze Greenidge, and Atiyah Mohamed. 2020. Wrestling with Race and Colonialism in Caribbean Agriculture: Toward a (Food) Sovereign and (Gender) Just Future. Geoforum 109: 106-110.

Beckford, George L. 1972. Persistent Poverty: Underdevelopment in Plantation Economies of the Third World. Oxford: Oxford University Press.

Best, Lloyd. 1968. Outlines of a Model of Pure Plantation Economy. Social and Economic Studies 17 (3): 283-326.

Caribbean Storm Network. 2011. Climatology of Caribbean Hurricanes: Trinidad and Tobago, https://stormcarib.com/climatology/ TTPP_all_isl.htm. Accessed 10 Apr 2020.

Briggs, Laura. 2003. Reproducing Empire: Race, Sex, Science, and US Imperialism in Puerto Rico, vol. 11. Berkeley: University of California Press.

Fanon, Frantz. 1963. Les Damnés de la Terre. New York: Grove Press.

Gahman, Levi, and Gabrielle Thongs. 2020. Development Justice, A Proposal: Reckoning with Disaster, Catastrophe, and Climate Change in the Caribbean. Transactions of the Institute of British Geographers 45 (4): 763-778. https://doi.org/10.1111/tran.12369.

Girvan, Norman. 2015. Assessing Westminster in the Caribbean: Then and Now. Commonwealth \& Comparative Politics 53 (1): 95-107.

Greenidge, Adaeze, and Levi Gahman. 2020. Of "Madness", Against Babylon: A Story of Resistance, (Mis)representation, and Paradox in the Caribbean. Political Geography 80: 102188.

Grove, Kevin. 2014. Biopolitics and Adaptation: Governing Socioecological Contingency through Climate Change and Disaster Studies. Geography Compass 8 (3): 198-210.

Hares, Sophie. 2016. Tackling Heavy Caribbean Debt is Key to Future Disaster Protection, Leaders Say, Thompson Reuters Foundation, https://www.reuters.com/article/us-caribbean-debt-restructure/ tackling-heavy-caribbean-debt-is-key-to-future-disaster-prote ction-leaders-say-idUSKCN1IW33T. Accessed 10 Apr 2020.

Hemingway, Laura, and Mark Priestley. 2014. Natural Hazards, Human Vulnerability and Disabling Societies: A Disaster for Disabled People? Review of Disability Studies: An International Journal 2 (3): $1-13$.

Intergovernmental Panel on Climate Change (IPCC). 2014. Climate Change 2014-Impacts, Adaptation and Vulnerability: Regional Aspects. Cambridge University Press.

Jones, Claudia. 2017. An End to the Neglect of the Problems of the Negro Woman! Revista Estudos Feministas 25 (3): 1001-1016.

Karmalkar, Ambarish V. A., Michael Taylor, Jayaka Campbell, Tannecia S. Stephenson, Mark George New, Abel Centella-Artola, Arboldo Bezanilla, and John Charlery. 2013. A Review of Observed and Projected Changes in Climate for the Islands in the Caribbean. Atmosfera 26: 283-309.

Kahn, Matthew E. 2005. The Death Toll from Natural Disasters: The Role of Income, Geography, and Institutions. The Review of Economics and Statistics 87 (2): 271-284.

Levitt, Kari. 2005. Reclaiming Development: Independent Thought and Caribbean Community. Kingston: Ian Randle.

Milken Institute of Public Health. 2018. Ascertainment of the Estimated Excess Mortality from Hurricane María in Puerto Rico, https://prstudy.publichealth.gwu.edu/sites/prstudy.publichealth. gwu.edu/files/reports/Acertainment $\% 20$ of $\% 20$ the $\% 20$ Estimated $\%$ 20Excess $\% 20$ Mortality $\% 20$ from $\% 20$ Hurricane $\% 20$ Maria $\% 20$ in $\%$ 20Puerto\%20Rico.pdf. Accessed 10 Apr 2020.

Mohanty, Chandra Talpade. 1988. Under Western Eyes: Feminist Scholarship and Colonial Discourses. Feminist Review 30 (1): 61-88.

Mollett, Sharlene. 2016. The Power to Plunder: Rethinking Land Grabbing in Latin America. Antipode 48 (2): 412-432. 
Noxolo, Patricia. 2018. Caribbean In/Securities: An Introduction. Small Axe 22 (3): 37-46.

Penning-Rowsell, Edmund, Peter Floyd, David Ramsbottom, and Suresh Surendran. 2005. Estimating Injury and Loss of Life in Floods: A Deterministic Framework. Natural Hazards 36 (1): 43-64.

Phipps, Claire. 2017. Irma's Destruction: Island by Island, The Guardian, https://www.theguardian.com/world/2017/sep/07/irma-destr uction-island-by-island-hurricane. Accessed 10 Apr 2020.

Pulwarty, Roger S., Leonard A. Nurse, and Ulric O. Trotz. 2010. Caribbean Islands in a Changing Climate. Environment: Science and Policy for Sustainable Development 52 (6): 16-27.

Rahnema, Majid, and Victoria Bawtree. 1997. The Post-development Reader. London: Zed Books.

ReliefWeb. 2019. Hurricane Dorian: WFP Support to the NEMA/ CDEMA-led humanitarian response in the Bahamas, Situation Report \#02. World Food Programme (Report). 6 September 2019, https://reliefweb.int/report/bahamas/hurricane-dorian-wfp-suppo rt-nemacdema-led-humanitarian-response-bahamas-situation. Accessed 10 Apr 2020.

Rhiney, Kevon. 2018. Global Change, Vulnerability, and the Coproduction of Resilience among Caribbean Farmers. Small Axe 3 (57): 68-80.

Rodney, Walter. 1972. How Europe Underdeveloped Africa. London: Bogle-L'Ouverture Publications.

Rowley, Michelle V. 2003. A Feminist Oxymoron: Globally GenderConscious Development. In Confronting Power, Theorizing Gender: Interdisciplinary Perspectives in the Caribbean, ed. E. Barriteau, 75-100. University of West Indies Press.

Scaramutti, Carolina, Christopher P. Salas-Wright, Saskia R. Vos and Seth J. Schwartz. 2019. The mental health impact of Hurricane Maria on Puerto Ricans in Puerto Rico and Florida, Disaster Medicine and Public Health Preparedness Report, http://www. trbas.com/media/media/acrobat/2019-02/70017943170700-01092 735.pdf.

Sealey-Huggins, Leon. 2017. " $1.5{ }^{\circ} \mathrm{C}$ to stay alive": Climate Change, Imperialism and Justice for the Caribbean. Third World Quarterly 38 (11): 2444-2463.
Sheller, Mimi. 2018. Caribbean Futures in the Offshore Anthropocene: Debt, Disaster, and Duration. Environment and Planning D: Society and Space 36 (6): 971-986.

Skerrit, Roosevelt. 2017. United Nations General Assembly 72nd Session Statement. United Nations, https://gadebate.un.org/sites/ default/files/gastatements/72/dm_en.pdf. Accessed 10 Apr 2020.

Sotomayor, Aurea María, Juan Carlos Rodríguez, Sheila Vélez Martínez, Myrna García-Calderón, Lourdes Dávila, Nemir Matos Cintrón, Adriana Garriga-Lópex, Luis Othoniel Rosa and César A. Salgado. 2017. The Cruelest Storm: Academics Speak Out for Puerto Rico, Common Dreams, https://www.commondreams. org/views/2017/09/30/cruelest-storm-200-academics-speak-outpuerto-rico. Accessed 10 April 2020.

Stapenhurst, Frederick, Anthony Staddon, Rasheed Draman and Louis Imbeau. 2018. Parliamentary Oversight and Corruption in the Caribbean: Comparing Trinidad and Tobago and Grenada. Commonwealth and Comparative Politics 56 (4): 493-522.

Suliman, Adela. 2018. Hurricane-hit Dominica Hurries to Prepare for Next Storm Season, ReliefWeb. Thomson Reuters Foundation, https://reliefweb.int/report/dominica/hurricane-hit-dominica-hurri es-prepare-next-storm-season. Accessed 10 April 2020.

Taylor, Michael A., Tannecia S. Stephenson, A. Anthony Chen, and Kimberly A. Stephenson. 2012. Climate Change and the Caribbean: Review and Response. Caribbean Studies 40 (2): 169-200.

Trotz, Ulric, and Sharon Lindo. 2013. Vulnerability and Resilience Building in CARICOM Countries. Small Island Digest 2: 25-39.

Wisner, Ben, Piers Blaikie, Terry Cannon, and Ian Davis. 2014. At Risk: Natural Hazards, People's Vulnerability and Disasters. London: Routledge.

Young, Ruth C. 1976. The Structural Context of Caribbean Agriculture: A Comparative Study. The Journal of Developing Areas 10 (4): 425-444.

Publisher's Note Springer Nature remains neutral with regard to jurisdictional claims in published maps and institutional affiliations. 